\title{
護岸ブロックの抗力・揚力係数、および相当粗度 の計測方法について
}

\author{
Measuring method of drag coefficient, lift coefficient and equivalent \\ roughness of revetment block
}

\author{
山本晃一 ${ }^{1} \cdot$ 林建二郎 ${ }^{2} \cdot{\text { 関根正人 }{ }^{3} \cdot \text { 藤田光一 }{ }^{4} \cdot \text { 田村正秀 }}^{5} \cdot$ 西村晋 $^{6} \cdot$ 浜口憲一郎 ${ }^{7}$ \\ Kouichi YAMAMOTO, Kenjirou HAYASI , Masato SENKINE , Kouichi FUJITA, Masahide TAMURA, \\ Susumu NISIMURA and Kenichirou HAMAGUCHI \\ ${ }^{1}$ 正会員 工博 河川環境管理財団 東京都中央区入船 $1 丁$ 目 9 番 12 号 \\ 2 正会員 工博 防衛大学校 神奈川県横須賀市走水 1-10-20 \\ ${ }^{3}$ 正会員 工博 早稲田大学理工学部 東京都新宿区大久保 3-4-1 \\ ${ }^{4}$ 正会員 工博 建設省土木研究所河川研究室長 茨城県つくば市旭一 1 \\ ` 7吅-会員 工博 財団法人土木研究センター 専務理事 東京都台東区台東 1 丁目 6-4 \\ ${ }^{6}$ 正会員 財団法人土木研究センター 研究開発一部主任研究員 東京都台東区台東 1 丁目 6-4 \\ ${ }^{7}$ 正会員 農修 パシフィックコンサルタンツ（株）筑波実験場＼cjkstart茨城㛜つくば市作谷 642-1
}

\begin{abstract}
This study examines measuring methods of drag coefficient, lift coefficient and equivalent roughness that are necessary for mechanical design of revetment blocks set on river banks. The setting method of blocks and the influence of the Reynolds number on drag force and lift force are examined by checking the experimental results. A standard testing method which is capable to estimate the characteristics of blocks, taking the error of mesurment into account and the treatment of fluctuation of hydraulic force on the block are shown in this paper.
\end{abstract}

Key Words : Hydraulic force, Revetment block,Equivalent block,Roughness,Drag coefficient Lift coefficient

\section{1. はじめに}

護岸は堤防および低水路河岸を降水や流水の浸 食作用に対して防護することを目的として設置され るものである。近年では親水性・景観・生態系の保 全・再生などの機能を有する新しい護岸工種の開発 が進められている。護岸の設計法は現場の実践・経 験を通して工夫されたものであり、力学的な設計法 となっていないため、新たな護岸ブロックの安全性 の照査はすぐにはできないものであったが、平成 11 年 2 月に財団法人国土開発技術研究センターより 「護岸の力学設計法」が発刊され、護岸ブロックに 関する照査が可能となってきた。
しかしながら、護岸ブロックの流水に対する安定 性の照査には、護岸ブロックの水理学的特性を示す 抗力・揚力係数や相当粗度が必要であるが、標準的 な試験法については定められていなかった。

そこで、財団法人土木研究センターに大学・建設 省土木研究所·建設省の関係者をメンバーとする「護 岸ブロック試験法検討委員会」を設置し、実際に水 理実験を実施して、問題点の抽出、計測法の改良、 試験法の確定を行ってきた。

計測方法の検討にあたっては、護岸ブロックの種 類が多いことから、計測が限られた試験装置を持つ 所でしか実施できないものとならないよう配慮した。

本論文に示した実験計測により得られた知見 
を「護岸ブロックの試験法マニュアル」に反映し、 試験法として整理を行う予定である。

\section{2. 実験の概要}

\section{(1) 測定項目}

実験では、「護岸の力学設計法」に用いられる以 下の $4 つ の$ 項目について計測を行い、各值の計測方 法について検討を行った。

(1) 単体設置時の抗力・揚力係数

(2) 群体設置時の抗力・揚力係数

(3) 群体上流端のブロックに作用する抗力・揚力 による回転半径

(4) 相当粗度

実験では、計測用のブロックを単体、群体の中央、 群体上流端に設置し、各状態でのブロックに作用す る抗力・揚力・回転モーメントについて分力計を用 いて計測を行い、測定法の改良を加え、試験法の立 案を図った。

\section{(2) 水路施設}

試験検討に用いた水路は図-1 に示す幅 1m、長さ 26m の直線水路であり、計測用ブロックは水路上流 から $16.5 \mathrm{~m}$ 地点の水路中央部に設置した。

(3)通水条件

実験では、レイノルズ数の変化による抗力・揚力
への影響等を把握するため、水位を一定 $(30 \mathrm{~cm}$ 程度) に保った状態で流量を変化させ通水を行った。流量 は最大 $3001 / \mathrm{s}$ とし、5段階に流量を変化させ計測を 行った。

\section{(4) 計測機器}

ブロックに作用する抗力・揚力の流体力について は、表-1に示す 4 分力計を用いて計測を行った。

流体力はブロック重量に較べ小さい事が予想さ れたため分力計については下記に示す精度の機器を 用いた。また、流速については鉛直 2 次元電磁流速 計を用いて水深方向に $10 \mathrm{~mm}$ 間隔で計測を行った。

表-1 4 分力計機器性能表

\begin{tabular}{|l|l|}
\hline 型式 & 歪みゲージ式 4 分力計 \\
\hline & $\mathrm{F}=2.04 \mathrm{~kg}(20 \mathrm{~N})$ \\
& $\mathrm{F} \mathrm{y}=2.04 \mathrm{~kg}(20 \mathrm{~N})$ \\
& $\mathrm{F}=2.04 \mathrm{~kg}(20 \mathrm{~N})$ \\
& $\mathrm{My}=1.02 \mathrm{~kg}-\mathrm{m}(10 \mathrm{~N}-\mathrm{m})$ \\
\hline 定格負荷 & 約 $1000 \times 10^{-6}$ \\
\hline 非直線性 & $\pm 0.2 \% \mathrm{FS}$ \\
\hline ヒシテリシス & $\pm 0.2 \% \mathrm{FS}$ \\
\hline 干渉度 & $\pm 3 \% \mathrm{FS} / \mathrm{FS}$ \\
\hline ゼロ点の温度影響 & $\pm 0.01 \% \mathrm{FS} /{ }^{\circ} \mathrm{C}$ \\
\hline 感度の温度影響 & $\pm 0.05 \% \mathrm{Reading} /{ }^{\circ} \mathrm{C}$ \\
\hline
\end{tabular}

(5)試験ブロックの形状

試験ブロックは図-2 に示す 8 ブロックについて 試験を行った。

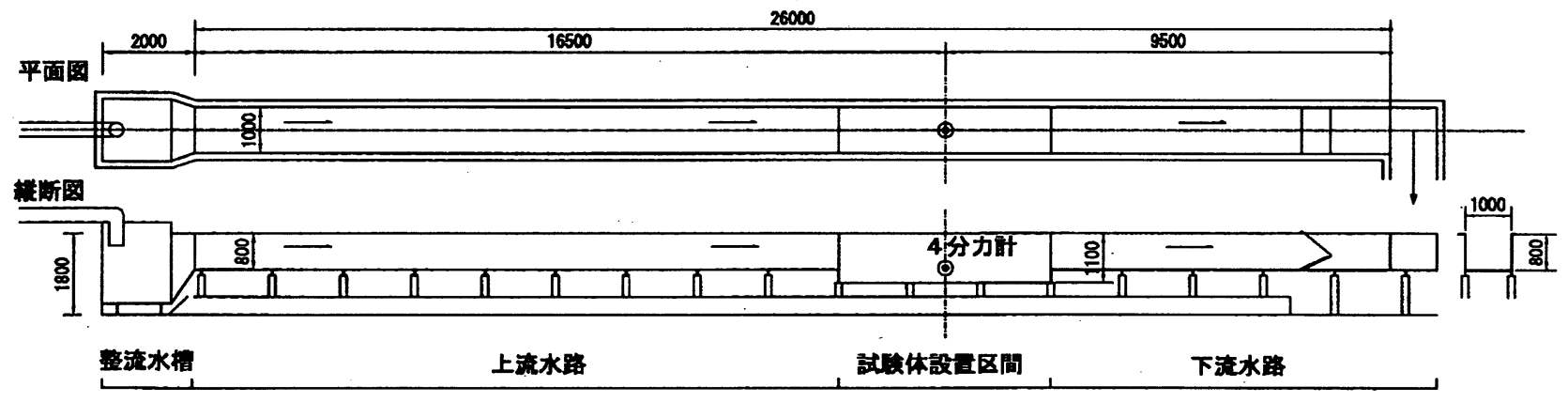

図一 1 試験水路施設（単位 $\mathrm{mm}$ ）

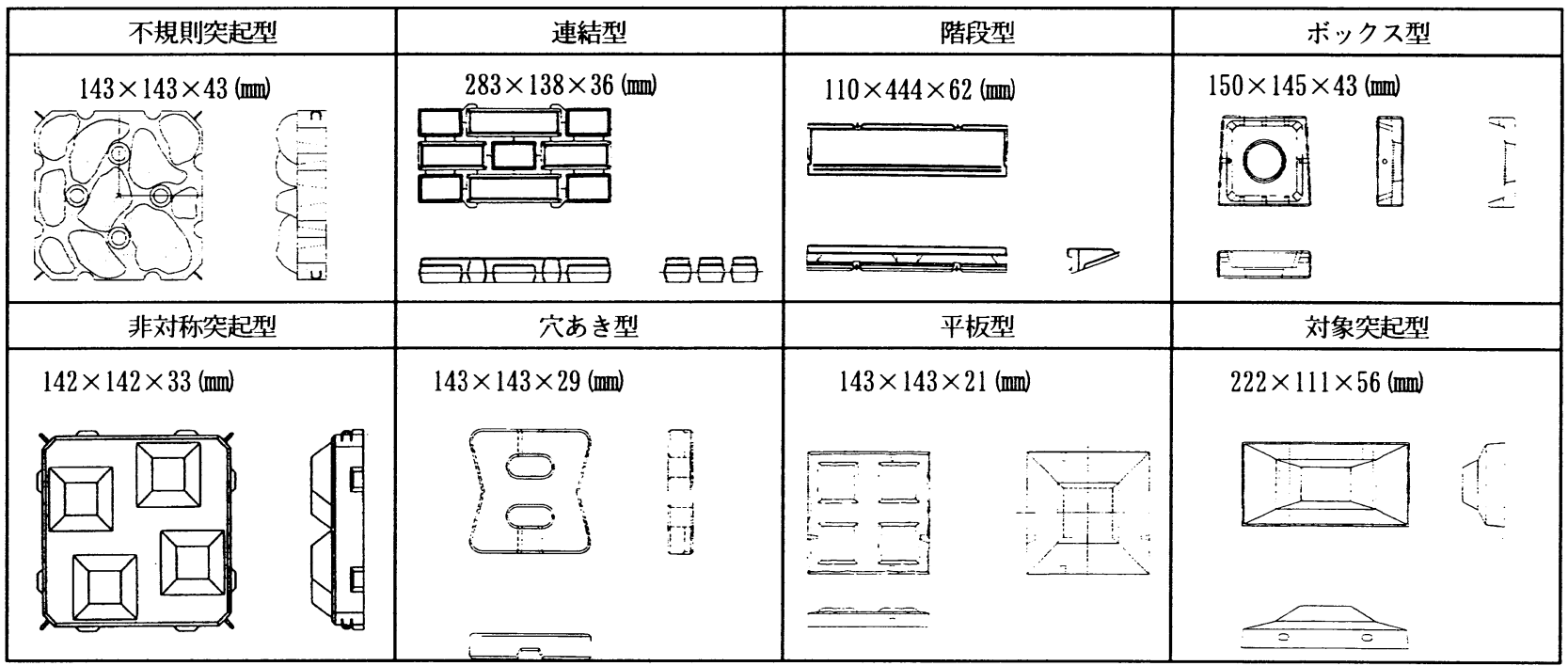

図 -2 試験プロック一覧 


\section{(6) ブロックの設置について}

ブロックの抗力・揚力の計測は、現地における流 れと同様な状況となるような条件下で実験を行う必 要がある。

実験においては、水路特性による影響、境界層の 発達状況を考慮し以下のようにブロックを設置した。 (1)ブロックの設置：群体試験では横断方向に 5 個以 上設置した。

(2)水深 : ブロック高の 5 倍、突起高の 10 倍以上を 確保し、側壁の影響を考慮して水路幅の $1 / 3$ 程度の水深とした。(襧津 $\left.{ }^{4}\right)$ らによると $\mathrm{B} / \mathrm{H}$ は 5 以上とされているが、底面と側壁の粗 度が大きく異なることから試験施設を考慮 してB/Hを 3 程度とした。)

(3)水路長 : 境界層の発達状態を考慮し、単体ブロッ ク試験では、水路底面に現地換算 $2 \mathrm{~cm}$ 程度の突 起型粗度（2３mm 砂粒）を設置し、試験ブロッ クの位置に置いて境界層が十分発達するように 上流区間を設けた。

\section{(7) 抗力、揚力係数、相当粗度の表示}

本試験における表示している值は以下の算定式 による。

(1)レイノルズ数の代表長

単体ブロック時 : ブロック高さ

群体ブロック時：ブロック突起高

(2)抗力・揚力係数

$$
\mathrm{D}=\frac{1}{2} \rho \mathrm{C}_{\mathrm{d}} \mathrm{A}_{\mathrm{d}} \mathrm{V}_{\mathrm{d}}{ }^{2} \quad \mathrm{~L}=\frac{1}{2} \rho \mathrm{C}_{\mathrm{L}} \mathrm{A}_{\mathrm{b}} \mathrm{V}_{\mathrm{d}}{ }^{2}
$$

$\mathrm{C}_{\mathrm{D}}\left(\mathrm{C}_{\mathrm{L}}\right)$ : 抗力係数 (揚力係数)

$A_{d}\left(A_{b}\right)$ : 抗力 (揚力) 作用面積 $\left(\mathrm{m}^{2}\right)$

$\mathrm{v}_{\mathrm{d}}:$ ブロック近傍流速 (m/s)

$\mathrm{D}(\mathrm{L})$ : 計測された抗力 $(\mathrm{N}) 、(\mathrm{kgf})$

$\rho:$ 流体の密度 $\left(\mathrm{kgf} / \mathrm{m}^{3} \cdot \mathrm{S}^{2} / \mathrm{m}^{4}\right)$

抗力作用面積：流九に対する全投影面積

揚力作用面積 : 設置面に垂直な全投影面積

(3)ブロック近傍流速 $\mathrm{v}_{\mathrm{d}}$ 単体ブロック時 : ブロック天端位置での流速 群体ブロック時 : 相当粗度高さでの流速

(4)相当粗度

$$
\frac{V_{0}}{U .}=6.0+5.75 * \log _{10} H_{d} / K_{s}
$$

$\mathrm{Ks}$ ：相当粗度 $(\mathrm{m}) 、 \mathrm{v}_{0}$ ：平均流速 $(\mathrm{m} / \mathrm{s}) 、 \mathrm{u}_{*}$ ：摩擦 速度 $(\mathrm{m} / \mathrm{s}) 、 \mathrm{H}_{\mathrm{d}}$ : 水深 (m)

・摩擦速度を水面勾配から算定

$$
\begin{aligned}
& \mathrm{U}_{*}=\sqrt{\mathrm{g} \mathrm{h_{ \textrm {m } } \mathrm { i }}} \\
& \text { ここに、 } \mathrm{i} \text { : 水面勾配 } \mathrm{h}_{\mathrm{a}} \text { : 水深 }(\mathrm{m})
\end{aligned}
$$

・摩擦速度を群体中の抗力から算定する方法

$$
\mathrm{U}_{*}=\sqrt{\frac{\mathrm{D}}{\rho \cdot \mathrm{Ab}}}(\text { 抗力加算定 })
$$

\section{3. 実験結果に基づく考察}

(1)計測值のフィルタリング

分力計を用いた抗力・揚力の計測は、分力計から の出力を $30 \mathrm{hz}$ のサンプリング間隔によりデーター 収録を行い、計測された波形から抗力・揚力の平均 値の算定を行った。

計測結果の評価にあたっては分力計の振動特性 について以下の状態での固有振動特性の検討を行い、 計測值のフィルター処理の方法について検討した。

(1) 分力計単体の固有振動特性

(2) 分力計水路水中設置状態の固有振動特性

(3) ブロックを設置した流体中の振動特性

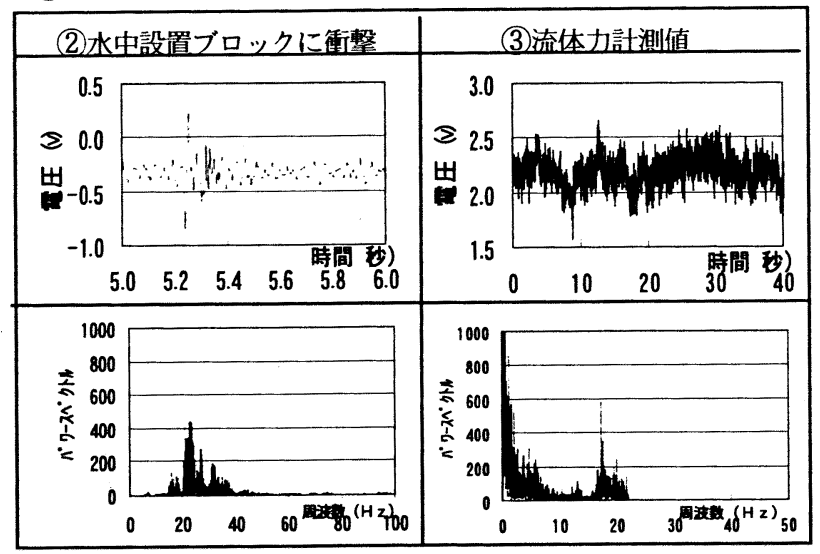

図ー3 計測波形とパワースペクトル

(2)、(3)の状態での分力計の計測波形、パワースペク トルを図-3に示す。(1)の分力計自体は約 $120 \mathrm{~Hz}$ 程度 の高い固有振動数特性を示すが、水路に設置した状 態では給水ポンプなどの振動が水路から分力計に影 響を及ぼすとともに、ブロックの設置棒やブロック 重量による慣性力等により固有振動数の低減が見ら れる。

通水中の計測値を見ると $5 \mathrm{~Hz}$ 以下の周波数帯に卓 越したスペクトルが見られ、また、スペクトル值と しても卓越した值を示しており、これが流体力によ る抗力・揚力の周波数と判断される。そこで、実験 の計測値については $5 \mathrm{~Hz}$ のフィルターにより平均化 を行い係数の算定などを行った。

ブロックを設置し流体中で計測したブロックの 振動の平均値からのずれの分布特性を図-4 に示す が、振動波形はほぼ正規分布となっている事から、 振動特性として標準偏差 $(\sigma)$ を求めることとした。

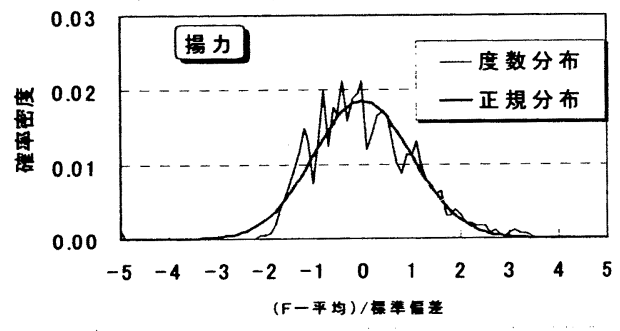

図一，振動波形の分布特性 


\section{(2) 計測の精度}

分力計による抗力・揚力の計測においては計測器 の定格負荷に対する計測値の比率が小さくなった場 合、計測値の精度が問題となる。図-5に抗力值から 評価した摩擦速度を用いて求めた群体の相当粗度と 抗力の対レンジ比の関係を示す。群体設置時におい ては、単体設置時などに較べブロックに作用する抗 力は小さく、計測された抗力の対レンジ比が $0.5 \% を$ 下回ると抗力が計測器の精度から過大に計測され、 相当粗度が大きく評価される事となる。レイノルズ 数は $10^{4}$ の領域であり、これは主に計測器の精度に よるものと判断される。

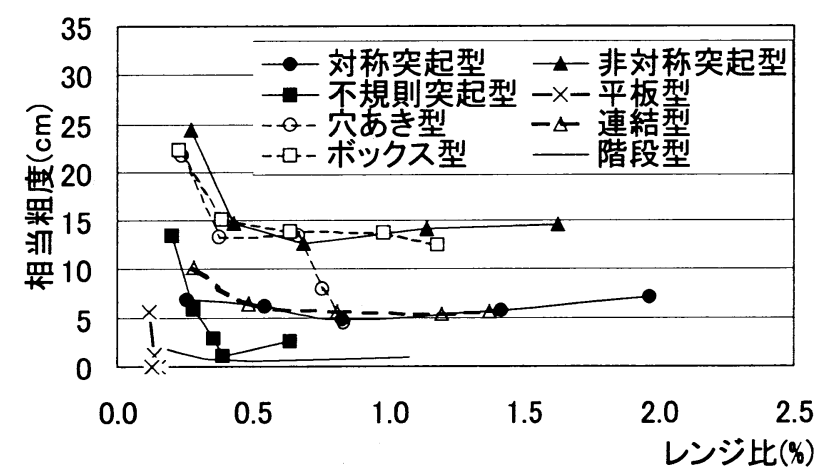

図ー5 対レンジ比に対する相当粗度

\section{(3) ブロック設置長の影響}

群体にブロックを敷設した場合の群体中央部の ブロックに作用する抗力・揚力は、試験ブロック上 流部に設置されるブロック数により上流境界層の発 達が異なり抗力・揚力が変化する。

そこで、上流に設置するブロック数を変化させて

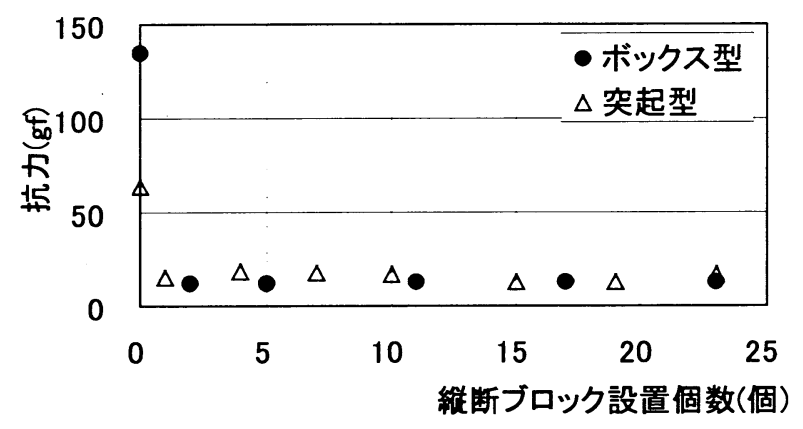

図-6 ブロック設置範囲と抗力の関係

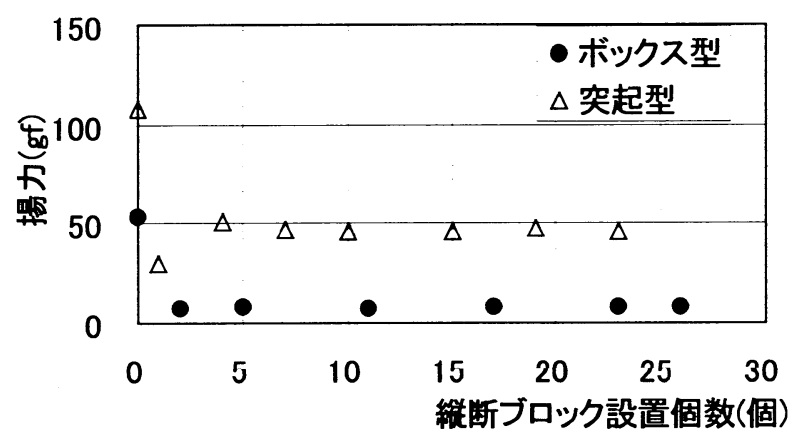

図-7 ブロック設置範囲と揚力の関係
設置個数による抗力・揚力の影響を検討した。図一 6, - にブロック個数の変化に対する揚力・抗力の変 化を示す。突起型ブロックでは上流ブロックの設置 個数が 5 個程度からほぼ一定となっているがう、ボ ックス型のブロックでは 2 個程度から一定の抗力 · 揚力となる。これは、ボックス型が全面的な剥離を 伴う流れとなるのに対し、突起型では突起部下流部 においてのみ剥離渦が生じるためと考えられる。

\section{(4) レイノルズ数の影響}

流体中に置かれたブロックに作用する抗力・揚力 はレイノルズ数の変化によって影響を受ける。実河 道でのレイノルズ数が $10^{5} \sim 10^{6}$ 程度であることを考 慮すると同程度のレイノルズ数の条件で試験を行う ことが望ましいが、施設規模が巨大となり実際には 実施不可能である。抗力・揚力係数は、レイノルズ 数がある值以上を境に一定の傾向を示すことが分か ってる。そこで、各ブロックについてレイノルズ数 を変化させた試験を行い、レイノルズ数の变化が抗 力・揚力に影響を及ぼす範囲について検討した。

試験結果について図-8，10 に示すように抗力係数 はレイノルズ数が $5 \times 10^{4}$ 程度でほぼ一定の傾向を 示した。また、図-9、11に示すように揚力係数につ いては $10^{4}$ のオーダーではほぼ一定の值となること が確認された。ほぼ一定になると判断されるレイノ ルズ数についてはブロック形状により差異はあるが、 ほぼ $5 \times 10^{4}$ 以上の範囲においては一定の傾向を示 すと判断される。

図-8 に示す単体試験において対称突起型や連結 型など表面抵抗が大きなブロックは、レイノルズ数 の低減により抗力係数の著しい増加が見られ、一定 值に較べ約 2 倍程度大きな值となっている。レイノ ルズ数が小さな範囲では形状抵抗に較べ表面抵抗が 大きな比率になると考えられるが、増加率について は表面抵抗のみでは大きすぎると考えられ、その要 因については今後検討する事が必要である。なお、 群体についてはレイノルズ数が小さい場合は (2)に 示したように測定精度に問題があるが、単体時には 抗力が大きく計測器の精度を原因とするわけにはい かない。

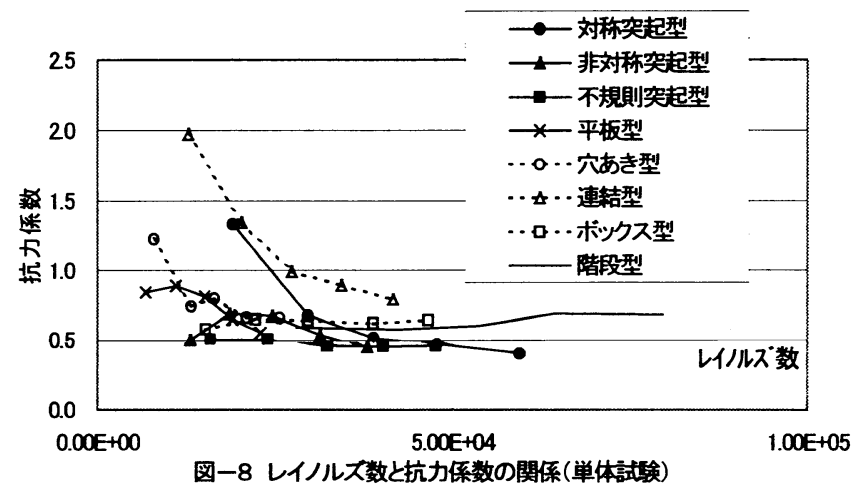




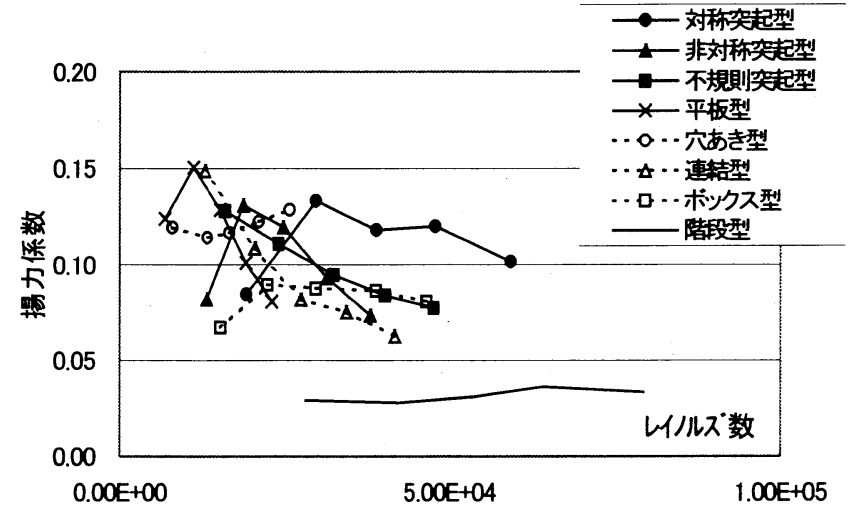

図ー9 レイルルス数と揚力係数の関係(単体訌渝)
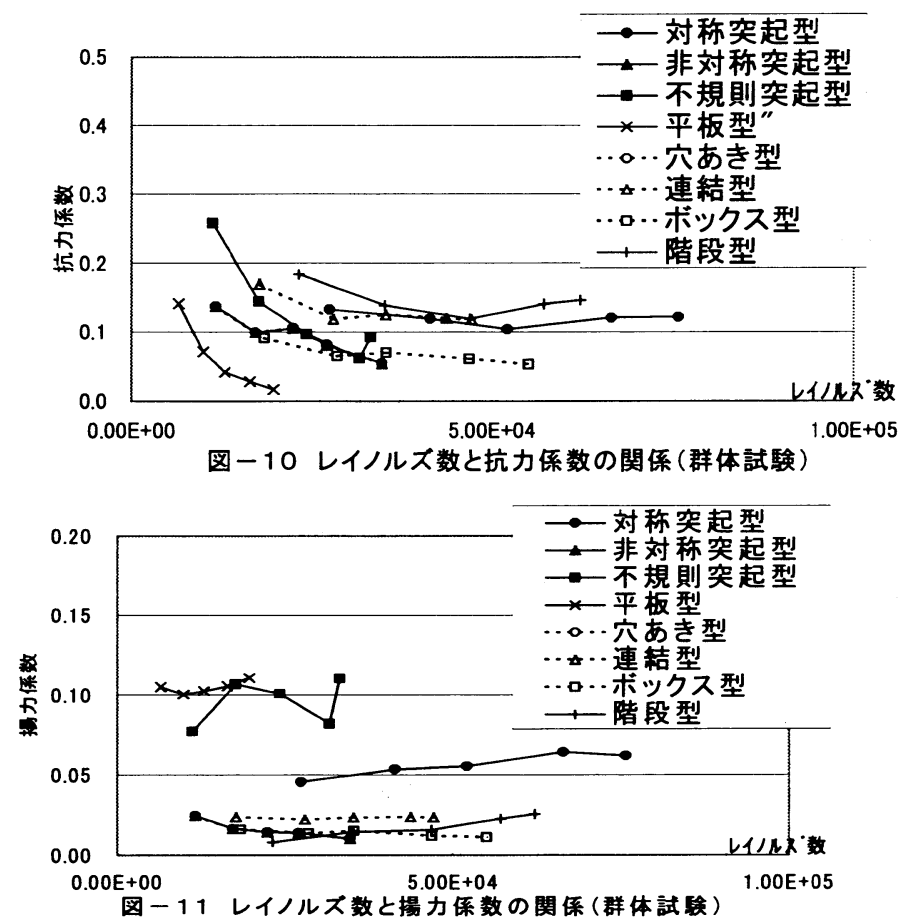

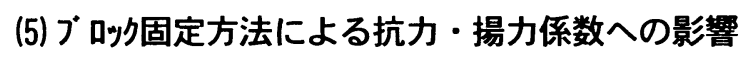

試験ブロックを分力計に設置する方法としては 図-12 にすように分力計に設置した載荷棒にブロッ クを取り付ける方式とした。載荷棒については剛性 が小さいと固有振動数が低減するため、 $10 \mathrm{~mm}$ のステ ンレス鋼棒を用いた。載荷棒と水路床の隙間は極力 狭く設置する事とし、本試験では $1 \mathrm{~mm}$ 程度とした。

ブロックと水路床の隙間については隙間が広いと 水路床とブロック底面に流れが生じ、揚力に影響が 生じると考えられた。そこで、試験では水路床とブ ロック底面の隙間を変化させた場合のブロック底面 の圧力分布と揚力について計測を行い、その影響を 調べた。図-13 にブロック底面の圧力水頭を計測し たマノメータ位置を示し、図-14 には水深と底面圧 力水頭を示し、図-15 には底面圧力の平均値とブロ ックと河床の隙間の関係を示す。単体ブロック試験 においては境界層の発達のため河床に粗度 $\left(\mathrm{k}_{\mathrm{s}}: 2\right.$ 〜 $3 \mathrm{~mm}$ の砂）を設置している。粗面での鉛直流速仮想 原点を粗度頂部から $\delta=\mathrm{k}_{\mathrm{s}} / 4^{4)}$ の距離とすると、原 点下層厚に相当する隙間高（約 $2 \mathrm{~mm} ） に$ 対してはブ

ロック底面圧力は静水圧とほぼ同様な值となってい る。しかし、原点下層厚以上にブロック設置隙間が 開いている場合は、ブロック底面圧力により揚力が 影響を受ける。ブロックの設置精度を考慮するとブ ロック底面への流れの防止を図るスカートを設置す し、試験を行う必要があると判断される。

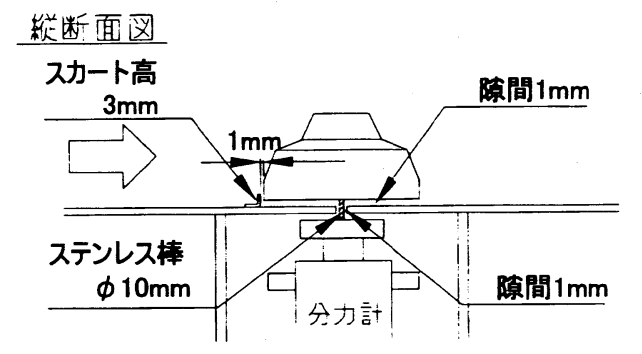

平面四
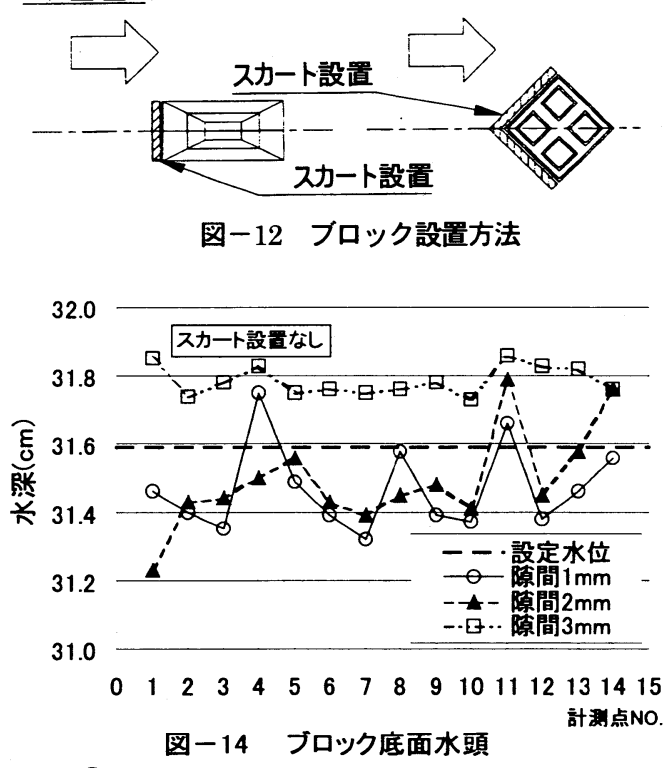

(11)

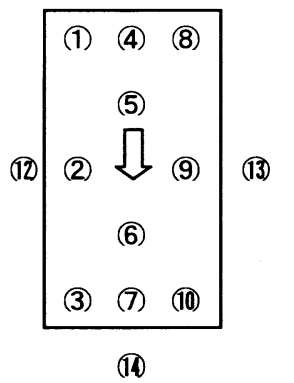

図-13 マノメー夕設置位置

\section{(6) 相当粗度の計測}

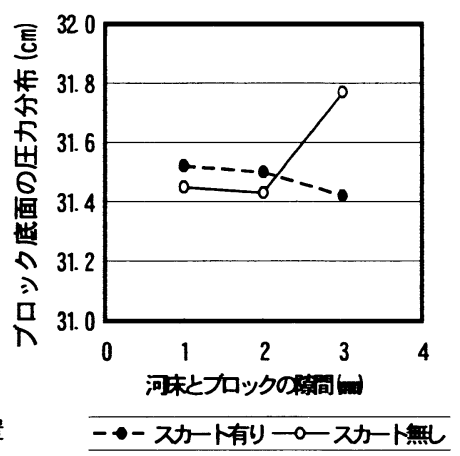

図-15 フロック底面睆間こよる影管

相当粗度の計測は、(1水面勾眍と水深により摩摖 速度を求める方法、(2)ブロックに作用する抗力から 摩擦速度を求める方法の 2 方法より摩擦速度を求め、 平均流速公式から相当粗度を算定する事とした。試 験においては試験ブロック位置で境界層が水面まで 十分発達している必要があり、境界層の発達につい ては流速の断面分布計測により確認を行った。

図-16 の試験ブロック設置地点の流速分布図に示 すように試験水路において境界層が十分発達してい 
る事が分かる。このような流れの状態で、水面勾配 から摩擦速度を求めて算定した相当粗度と水面勾配 の関係を図-17 に示す。水面勾配が緩勾配になると 相当粗度が小さくなる傾向が見られる。水面勾配が 1/500 以下の結果については水面勾配の測定精度に 問題が生じるが、1/500 以上の勾配についても勾配 が大きくなると相当粗度が大きくなる傾向となって いる。抗力から求めた掃流力による相当粗度は $5 \times$ $10^{4}$ のレイノルズ数を越えると一定の傾向を示して いる。水面勾配が急になるとフルート数が大きくなり、 また相対水深 $\mathrm{Hm} / \mathrm{k} \mathrm{s}$ が小さい $(3 \sim 6)$ ことを考え ると水面の乱れ等の造波抵抗係数などの底面の摩擦 損失以外の損失が生じていると考えられる。ブロッ クの物性値の把握という観点から言うと相当粗度の 計測は抗力の測定による方法が良いと考えられるが、 勾配の急な河川での使用を考えると両者の実験を行 っておくべきである。
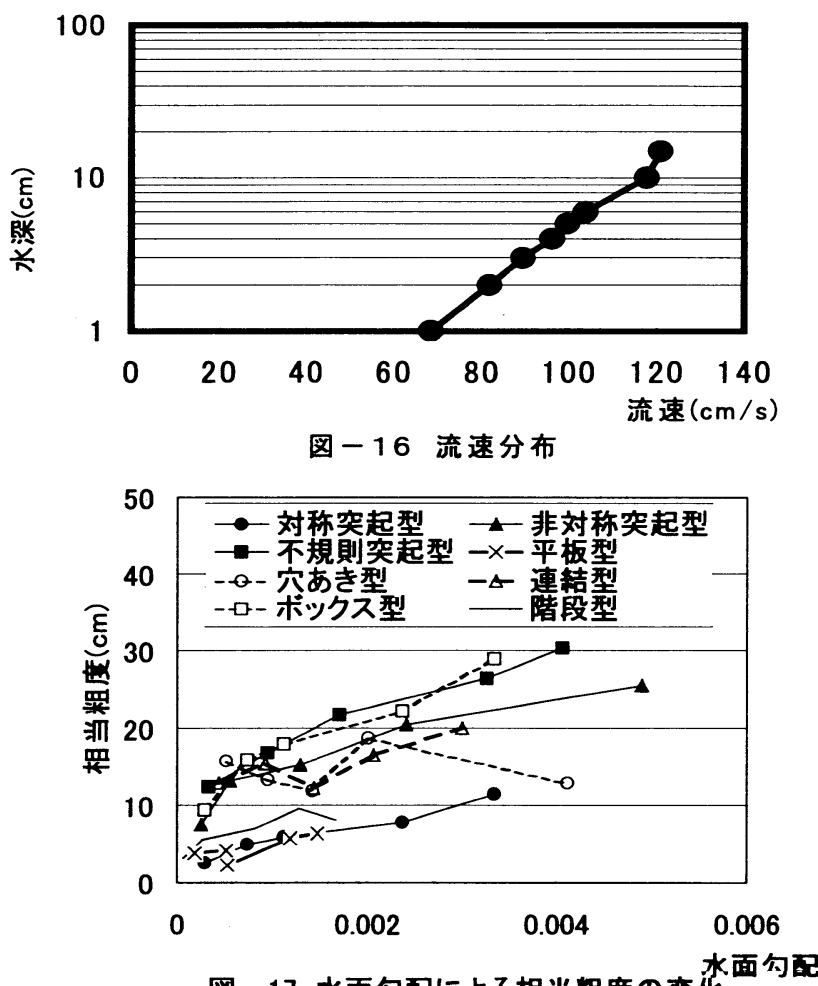

図-17 水面勾眍による相当粗度の変花

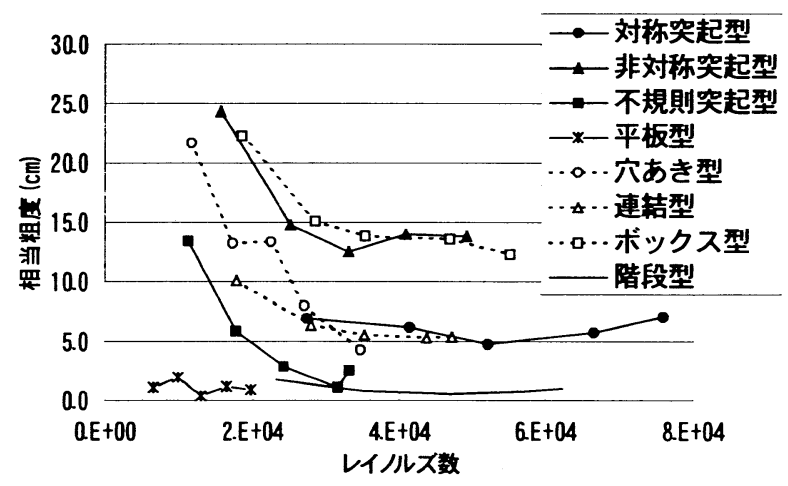

図-18
なお、平板型のブロックでは群体時に作用する抗 力が小さいため抗力の計測精度に問題が生じ、この ようなブロックについては水面勾配による計測精度 に問題が生じない十分な区間長を確保して相当粗度 など計測する事が必要である。

\section{4. おわりに}

本論文では 8 種類の形状の異なるブロックについ て抗力係数、揚力係数、相当粗度を計測し、ブロッ クの水理特性を示すと判断される試験条件や計測方 法について整理を行った。

試験条件としては、抗力係数、揚力係数がほぼ一 定の值を示すと判断されるレイノルズ数は $5 \times 10^{4}$ 程度であり、試験は比較的大きなレイノルズ数の領 域で行う事が必要である。

試験法としては、単体設置ブロック計測で揚力が 影響を受けるため、ブロックと水路床の間に流れが 生じないようにブロックを設置する事が必要であり、 計測值については計測器の振動特性を把握しフィル ター処理を行う事が必要である。

相当粗度の計測は、群体に設置したブロックに作 用する抗力から算定するが、計測器に対するレンジ 比が $0.5 \%$ 下回ると䛊差が大きくなる。また、相 当粗度が小さいブロックでは設置長を長くして水面 勾配から相当粗度を計測することが必要である。

既存ブロックの種類、新型ブロックの開発などを 考慮するとより簡易でブロック特有の水理特性を正 確に計測可能な手法について今後も試験法の改良を 行う事が必要であると考えている。

謝辞：本研究を行うにあたり協力を頂いた、建設省 治水課・海岸防災課、建設省土木研究所、財団法人 国土開発技術研究センター、ならびに実験資材の提 供を頂いた共和コンクリート工業株式会社、三菱マ テリアル建材株式会社、株式会社アドバンス、技研 興業株式会社の諾氏に謝意を表します。

参考文献

1) 土木学会編 : 水理公式集

2）財団法人国土開発技術研究センター編：護岸の 力学設計法、山海堂

3）笠木信秀・ 木村龍治 - 西岡通男 - 日野幹雄 - 保 原充 : 流体実験ハンドブック、朝倉書店

4) 螎津家久: 水理学・流体力学、朝倉書店

5) 福岡捷二・藤田光一・森田克史 : 護岸法覆工の 水理設計法に関する研究、土木研究所資料第 2635 号、昭和 63 年 4 月

(1999. 9. 30 受付) 